\title{
Rights, Performatives, and Promises in Karl Olivecrona's Legal Theory
}

\author{
MARTIN P. GOLDING
}

Abstract. Karl Olivecrona (1971) maintains that "right" is a "hollow word," and so also for some other legal terms. "Right," he says, "has no conceptual background." He arrives at this position after an examination of metaphysical and naturalistic accounts, including American legal realism. Some of Olivecrona's arguments will be evaluated here. His position is influenced by Hägerström's theory of legal language, but he argues that Hägerström fails to account for how such terms as "right," "duty," etc. function in legal discourse and why they are useful. A parallel approach is also found in Olivecrona's book The Problem of the Monetary Unit (1957). Olivecrona is left with the problem of how such "hollow" terms function. His explanation is largely psychological. Going beyond J. L. Austin's notion of performatory language, he introduces the idea of performatory imperatives. I propose to submit Olivecrona's approach to a critical examination. It is suggested that had he started from everyday, nonlegal promises and commitments he might well have ended up with a different theory of legal language.

Karl Olivecrona's book Law as Fact contains an intensive attack on metaphysical and naturalist accounts of such central legal terms as "right" and "duty" (Olivecrona 1971). A concise exposition of his approach is also found in an article, "Legal Language and Reality," published in 1962, where he uses this terminology to distinguish the different accounts. His primary problem is to explain what a right or duty really is, and how rights and duties can be created by operative facts such as verbal declarations. He describes himself as a theorist who wants to use scientifically correct concepts only, meaning by this "concepts corresponding to reality" (Olivecrona 1962, 153). As far as I can tell from Olivecrona's English-language writings, however, hardly any details are given of his conception of science. His gnomic reference to "concepts corresponding to reality" is not very enlightening, and its meaning has to be inferred from his work as a whole.

Because Olivecrona's general position is similar in some respects to that of Joseph W. Bingham's, it might be useful to take note of a few points. 
Bingham is often considered to be the first American legal realist, and his position is developed in an article published in 1912, "What Is the Law?" (Bingham 1912). His account of legal science is based on a general theory of science (see Golding 1986, 453-5). Every science studies sequences of concrete, "external" phenomena to determine their causes and effects, and to predict similar future sequences. In the case of legal science, the "field" it investigates "consists of external governmental phenomena and their concrete causes and effects" (Bingham 1912, 9). Knowledge of these phenomena may be generalized into rules and principles, and it is only when we have achieved an organized body of knowledge of this sort that we really have a science of law. But these rules and principles are only "mental tools" for the classification and communication of knowledge, similar to the generalizations of other sciences. Thus, the Boyle-Charles Gas Law $(p V=k T)$ is a mental tool for classifying and communicating knowledge about the behavior of gases; nothing in nature, no general fact, corresponds to it. So also, the legal generalizations do not denote any facts in the field of law because there are no general facts for them to denote: The rules, principles, and concepts exist only in the minds of individuals. Along the same lines, Bingham maintains that nothing external corresponds to such terms as "legal right" and "legal duty."

While Olivecrona's theory of law is not explicitly derived from a general theory of science, he seems to have been a sort of nominalist, as Morris R. Cohen said of Bingham (Cohen 1982, 208). Olivecrona, too, maintains that nothing corresponds to such a term as "legal right." But he seems to have gone even further in holding that "right" is a "hollow word" (Olivecrona $1962,163)$. What does that mean and how does Olivecrona reach that conclusion? Is it an empirical thesis or is it derived from his theory of meaning? We have to start with his critique of metaphysical and naturalist accounts of legal terminology. As mentioned, the problem is to explain what a right or duty really is, and how rights and duties can be created by operative facts such as verbal declarations. Olivecrona's procedure is to demonstrate that all these accounts fail, so that the problem remains intact. To this end, different sorts of criticisms are made of the various theories. His basic and recurrent argument emerges nonetheless in the treatment of the metaphysical account.

The central figures in the metaphysical account of rights are Grotius and Pufendorf who, despite their differences, define a right as a moral quality or faculty (qualitas or facultas moralis). Clearly, a right is not identical with a physical power that one person has over another; it is, as Olivecrona states, a moral power. It is established by an act of will by one party that is accepted by the other. The act of will is made known through a promise, a declaration of will, in which the declarer alienates a part of his liberty, his right to decide over his own actions, to the other party, the promisee. Olivecrona calls this power "mysterious," presumably because it is not directly observable. A 
legal right on this view, Olivecrona says, is a mystical power to be enforced by the state. We should mention, however, that this so-called metaphysical account is not confined to legal rights, for binding promises can be made in the state of nature. Moreover, there may be morally binding promises that the state might choose not to enforce. What is crucial is the operative fact, the declaration of will. We shall come back to this topic later, in the discussion of Olivecrona on performatives.

Grotius and Pufendorf were of course working within the theory of natural law, and in a very scholarly exposition Olivecrona goes on to argue that remnants of their position may be found even in legal positivist writers who negated the reality of rights. Wherever such remnants are found, the theories are rejected. Much of this exposition deals with proponents of the "imperative" (command) theory of law. Most of these writers are unknown, or at least unread, in Anglophone jurisprudence. The discussion is lengthy, and it will be enough to treat a few instances here, to illustrate his procedure. I shall also make a few critical comments.

He begins with Windscheid's will-power (Willensmacht) theory, which in essence is typical of a whole group of writers. A right is a power exerted by the will of one person over that of another. But no longer is it the result of an individual's power over his own actions which he has transferred to another. "Instead," Olivecrona explains, "it is the power of the legal order itself. The legal order commands the debtor to fulfill his obligation. But it has put this command at the disposal of the creditor; [.. .] the imperative of the state has become his imperative" (Olivecrona 1971, 148). The difficulty that Olivecrona finds in this position seems not only to be that a legal right is a mystical power enforced by the state, but also a problem of a different sort. It is that the theory is "wholly fictitious." A creditor does not direct a command to his debtor in claiming payment, and the owner of an object does not issue imperatives to the whole world to abstain from interfering with his use of it. "The right is held to exist by virtue of the law and certain operative facts; and its possessor need not issue any commands" (Olivecrona 1971, 149). So the problem of explaining what rights and duties are remains.

The criticism of Jhering contains an additional element (Olivecrona 1971, 151-4). Jhering remained a positivist of sorts, says Olivecrona, though he rejected the Willensmacht theory of rights. Jhering was concerned with the substantive content of the law and the reason for the creation of legal rights. Rights are bestowed in order to protect interests worthy of protection. A right is a legally protected interest, the legal security in enjoying certain advantages. Olivecrona finds this position to be involved and obscure. In his 1962 article, he states that this "interest" obviously is not an interest in a psychological sense, that is, presumably, in the sense in which someone may take an interest or be interested in something. Because someone can have a right without knowing it, he concludes that "the word can only be understood as a misleading expression for the mystical power" (Olivecrona 1962, 154). 
Jhering's theory may be obscure in various ways, but I don't see the difficulty here. There may be many things that are good for someone, to his advantage, things he doesn't know about (at least this is true in my case), but which are therefore in his interest. Some of these things may be protected by the law, and rise to the level of rights. I don't see any reason for saying that "the word can only be understood as a misleading expression for the mystical power." Olivecrona, it seems to me, is simply intent on sticking Jhering and other writers he opposes with the "mystical power" idea.

The American legal realists are taken as representative of one kind of naturalistic position. Olivecrona is somewhat sympathetic to their approach because they too wanted to see "law as fact," and to eliminate supernatural, non-empirical entities from the law. To this effect, he cites such figures as Justice Holmes, A. L. Corbin, and Felix Cohen. The basic move is to substitute statements concerning judicial action for statements about rights and duties in the traditional sense. Corbin's formulation is fairly typical:

When we state that some particular legal relation exists we are impliedly asserting the existence of certain facts, and we are expressing our present mental concept of the societal consequences that will normally follow in the future. A statement that a legal relation exists between $\mathrm{A}$ and $\mathrm{B}$ is a prediction as to what society acting through its courts or executive agents will do or not do for one against the other. (Olivecrona 1971, 172, from Corbin, 1919, 164; emphasis in the original)

What we have here, says Olivecrona, is a "redefinition" of legal concepts, including the concept of rights.

While Olivecrona can hardly accuse the realists of holding that a right is a mysterious power, he does make some critical observations about their approach (see Olivecrona 1962, 156-60). For one thing, the prediction theory doesn't give us workable concepts. There are too many "ifs" involved: if a claim is raised, if witnesses tell the truth, if the court believes them, etc. The second observation is more interesting, I think. The traditional concepts, he says, belong to the context of social reality and it is impossible to eliminate them from legal science. But the realists' redefinition does not explain the actual import and function of the traditional concepts. (A similar complaint is made against other theories.) This remark seems rather ironic. Olivecrona appears in accord with the view, attributed to the realists, that current legal concepts are "chimerical" (Olivecrona 1971, 174). Moreover, he in fact maintains, the idea of a right "does not signify anything at all; it does not even refer to something existing in imagination only, as the centaurs" (Olivecrona 1971, 183). It is a "hollow word." The term "right" is "not the expression of any notion at all" (Olivecrona 1962, 168). It has no "conceptual background" (Olivecrona 1962, 163).

These statements are rather obscure, in my opinion. I have no difficulty in mentally picturing (imagining) a centaur but I do have difficulty in 
picturing a "snark." This term, invented by Lewis Carroll (1876), is defined in the dictionary as a "chimerical animal of ill-defined characteristics and potentialities." However, while I also have trouble picturing what the symbol " $\square 2$ " refers to, I know it is meaningful. Here, I think it would have been useful to have had more details on Olivecrona's philosophy of science, particularly his views on the nature of theoretical terms that refer to unobservable entities. Human beings may someday see centaurs (God help us!), but no one will ever see, or even picture, a positron or a quark. It may be mentioned here that Olivecrona occasionally slips. While claiming that the term "right" is "not the expression of any notion at all," he also speaks of the "ideas of rights" that we have (Olivecrona 1947, 554; emphasis in original). What he means by this, I think, is not that there is a describable idea of a right but rather there merely is the idea that the term represents something. (See below regarding the monetary unit.)

It looks as though we here have an empirical thesis. By introspection Olivecrona knows that he has an idea of a centaur; he can picture one. But he cannot picture a right. "We have the word 'right' in the mind," he says, "but we find no image or representation designated by this word" (Olivecrona 1971, 167). The term "right," therefore, is "not the expression of any notion at all." On the other hand, if the term refers to a mystical power, as it does for Grotius and Pufendorf according to him, then there is no idea of a right because this mystical power is a "logical absurdity" (Olivecrona 1962, 163). He knows that such powers can not exist and that we can not have any idea of them. That this is the case appears to derive from his implicit theory of meaning and his implicit nominalist ontology. (We know that a perpetual motion machine can't exist, but that is because of the laws of physics.) So a question remains. If it is impossible to eliminate the language of rights from legal science, how can the significance of this language be explained? We shall come to Olivecrona's explanation below.

In any case, if "right" doesn't signify anything at all, what can be wrong with the American realists' redefinition, if the term is to be retained? Redefinition seems to be an acceptable procedure as part of a rational reconstruction of a field of knowledge or organized activity. I think, though, that Olivecrona has another point going, but he does not develop it. Rights and duties, he holds, not only do not belong to the sensible world, the world of facts, but it is also "of the very essence of our legal notions that rights and duties are not identical with any facts" (Olivecrona 1962, 156; emphasis supplied). With this intriguing remark Olivecrona may be intimating that the normative function of these terms is undercut if we try to reduce them to facts. His argument then is something like that of those philosophers who claimed that such terms as "good" lose their commendatory function if they are defined purely in factual, non-normative language. Given that "right" is a "hollow word" and "is not the expression of any notion at all," and that 
"it is impossible to eliminate rights from legal science," an account of legal language is desperately needed.

Most instructive is the discussion of Axel Hägerström in Olivecrona's 1962 article (160-9). (Hägerström's "deep impression" on him is explicitly mentioned in the Note to Olivecrona 1947, 556.) Hägerström, he says, gives a psychological and historical explanation of rights language. We cannot identify a right with a factual situation; a right (in private law) is believed to be created by operative facts but we cannot find such facts. We have a notion of the object of a right (an advantage) but what is the right itself? As Olivecrona puts it: "Hägerström says that it is a supernatural power; but this supernatural power is said to be a logical absurdity. [. . .] Hägerström sums up his analysis of the notion of a right by saying that one merely believes one's self to be endowed with a supernatural force in regard to things and persons, which is independent of one's natural power" (Olivecrona 1962, 165; emphasis in original). In psychological terms, then, a right is a feeling of power, but Olivecrona rejects this point. The historical explanation of rights language is that it is a survival of the primitive belief in word magic, just as magicians were believed to be able to effect changes in the world through the use of verbal formulas.

Olivecrona raises three objections against Hägerström. Firstly, law is inconceivable without rights and duties and, secondly, legal questions are discussed in terms of "rights" and "duties." Lastly, no jurist would admit that the idea of a legal right is that of a mysterious power. Olivecrona accepts these objections, but the last one is the most interesting of them. We cannot think of a right as a mysterious power, for such a power is nothing. And "right," as we have been told, is a hollow word. Yet it is the explanation of rights language as a survival of the primitive belief in word magic that is setting Olivecrona's problem. How can the use of a verbal formula ("I promise to meet you for lunch tomorrow") create rights or duties?

Before we turn to Olivecrona's answer to this question, it is useful to recall his criticism of the various theories. Aside from the objection to American legal realism that the realists' redefinition does not explain the actual import and function of the traditional concepts, his basic contention is the same throughout: The term "right" is not the name of any observable entity. A similar view is to be found in his 1957 book The Problem of the Monetary Unit: The terms "dollar" and "pound" are also hollow words. A pound, for instance, is not identical with the pound note; the pound note is held only to represent the pound. But don't we count numbers of dollars and pounds? How can this be done unless there were objects to be counted? He answers as follows:

Every possibility of finding anything denoted by the words dollar, pound, etc., as they are commonly used, seems to be excluded. When we speak of such units, we 
have before us the word itself-visually or auditively. Furthermore, we have the idea that the word denotes something, though we are unable to say what. This idea, however, makes it psychologically possible to count numbers of monetary units. But in reality, the something is nothing. There is only the word itself in conjunction with the idea that it denotes something. (Olivecrona 1957, 119)

Nowhere, then, are the pounds found except in speech; it is immaterial that the pounds are not objects. "The significant thing is that we talk about them in certain ways" (Olivecrona 1962,172). This speech is governed by rules; the word for the monetary unit plays an important role when employed according to law and custom; its function is technical, not emotional or volitional. (It is important to keep in mind that Olivecrona is talking about the monetary unit and not about money as a medium of exchange, though the two are related. He has a lot to say about the banking and credit systems.) The terms of legal language, "rights," "marriage," "contract," etc., too, have a technical function. The key to understanding this function is the sign function of the terms (Olivecrona 1971, 186-93; 1962, 182-91). His account is psychological.

There are permissive signs and prohibitive signs, for instance, green and red traffic lights. Green and red lights do not express any notions, he says; they are just signs. A red light causes the driver to stop. I suppose Olivecrona would say the same sort of thing about the words "stop" and "go," which of course can be and in fact have been used instead of traffic lights. Now it might be admitted that the lights or the words themselves do not express true or false statements (though they contextually might imply such statements). However, his claim that the lights or the words do not express any "notions" seems incorrect to me. I know what a red traffic light means even when I am not driving and no behavior of mine is being caused. It seems to be Olivecrona's position that because these signs and words do not refer to external sets of facts that can be described in terms of true of false statements they therefore do not express any notions. But this implication is not obviously correct.

It might be useful here to compare Olivecrona's position with that of Bingham's. For Bingham the concept of rights is a "mental tool," like our concepts of rules and principles. While nothing in reality corresponds to them, these mental tools enable us to classify and manipulate the "concrete" materials in the field of law. These mental tools, as ideas in the mind, have causal effects. So far, then, Olivecrona's position seems to be the same as Bingham's, but there is a difference. Bingham nowhere denies the reality of these ideas or the reality of the idea of a right. Olivecrona, however, claims that "right" is a "hollow word" with no conceptual content. We do not have an idea of a right but rather the idea that the term represents something. What we have, so to speak, is an idea of an idea. What is important for him is the word "right," which functions as a sign. Like the words for the monetary units, we have before us the word "visually or auditively." 
Olivecrona considers in some detail the idea of property and the expression "right of property." Certain consequential ideas are associated with them, an awareness of legal consequences; we only need the psychological connection. "The words 'right of property,'" he says, "may be hollow in the sense that they do not express any notion at all beyond the words themselves before the mind; nevertheless, they may evoke ideas of what one may, or may not, do in certain respects" (Olivecrona 1962,183). We never find the right of property itself; we find only the words. To maintain this psychological connection it is necessary that ownership be ascribed to someone only in accordance with certain rules. The word "right" has a technical function akin to the technical function of the words for monetary units, which depends on their being used in accordance with certain rules of law and custom. Thus, the expression "right of property" is a connecting link between two sets of rules: rules about acquisition of property, and penal rules, and rules about damages, etc. It has something like the role of a railway junction, and practically speaking this expression is indispensable.

As is to be expected, Olivecrona denies that sentences about rights are true or false, for that would presuppose that there is a reality to which they refer. What is still important, apparently, is the belief that they are true or false. But doesn't this in turn suggest that such sentences (" $A$ is the owner of $X$ ") are informative? On this matter he is a bit unclear. What information, he asks, is conveyed by saying $A$ is the owner of a house (Olivecrona 1962, 185; see also Olivecrona 1971, 193-9)? All I can do is learn about certain legal transactions which are held to give rise to right of ownership; I imply that A has legal title, but I need not know what legal title is. But no such information is conveyed; if we suppose that such a statement is made in conformity with legal rules about the acquisition of rights, the conclusion is that A will have legal title to a certain object. On the other hand he says that such statements are informative but not "in the way we believe them" (Olivecrona 1962, 188). I have trouble grasping the import of this remark. The explanation perhaps is that the statement about ownership is useful because it puts us "on the track" of the inquiries we have to make (Olivecrona 1971, 255).

In any case, what is crucial for Olivecrona is the distinction between the question of truth (which presupposes an external reality) and the question of conformity with legal and social rules (Olivecrona 1962, 188; see also Olivecrona 1971, 259-67). It is conformity with legal and social rules that makes the technical function of rights language possible. But what does this notion of conformity involve? It seems to me that Olivecrona is thinking of the law on analogy with a game, such as chess. The moves aren't true or false, but are rather legal or illegal, depending on conformity with the rules of the game. More drastically, he may be thinking of the law on analogy to a formalist conception of mathematics, according to which certain physical marks have no reference but are merely manipulated according to the rules. 
Whatever the case with chess or mathematics, I don't think that we can conceive of the law in this way. While I accept the distinction between the question of truth and the question of conformity with legal and social rules, I do not think it follows that the law has no ideational or conceptual content. As unclear as I am about the concept of contract, I recognize it to be different from that of property. A legal textbook on contracts may overlap a textbook on property, but they will not be identical books.

The sign function of the word "right" is only part of Olivecrona's explanation of its use. The other important part of the explanation is the performative use of language, which is relevant to the notion of operative facts generally. Performatives are discussed in two places: his 1962 article and his 1971 book. In both places it is held that performative utterances are not used to report facts; they describe nothing. Their purpose is to establish a new legal relationship; legal consequences are attached to the utterances. They are held to give rise to rights and duties or legal properties (see Olivecrona 1962,174). (It is interesting to note that John Searle, a leading theorist of performative language, speaks of "a quasi-magical power of bringing about changes in the world through our utterances" - Searle 1991, 384.)

In the 1962 article Olivecrona more or less takes over J. L. Austin's approach in How to Do Things with Words (1975), though he does not make reference to Austin's notion of locutionary, illocutionary, and perlocutionary acts (Austin 1975, 98-107). At some point, however, he became unhappy with Austin's approach, possibly because he saw that Austin's distinction between constatives (fact-stating language) and performatives breaks down. (This point is pretty much acknowledged by Austin himself.) The cardinal difficulty he finds in Austin is that Austin never explains the meaning of performative utterances. As Olivecrona writes in the 1971 book: "If the sentences describe no facts, if they are neither true nor false, and if they are not meaningless, their meaning ought to be described. ... But Austin never addressed himself to this task" (Olivecrona 1971, 235). Moreover, although Austin gives the examples of the use of "ritual phrases" in ceremonies of christening and marriage, he "omitted to discuss the nature of the supposed non-psychological effects of the ritual acts. [...] he lost sight of the fact that doing something with words consists in calling forth a supposed nonpsychological effect. To do things with words became merely uttering the words ('in appropriate circumstances')" (Olivecrona 1971, 237; emphasis supplied). Notice here the word "supposed." (There is now a large literature on performatives, but I shall stick to Olivecrona's unique account.)

The main innovation in the book is the introduction of the notion of performatory imperatives (Olivecrona 1971, 134, 218). Olivecrona is not interested in Austin's idea of explicit performatives and performative verbs, such as occur in the expressions "I apologize," "I congratulate," "I welcome." Austin, he says, "diluted" the category of performatives (Olivecrona 1971, 237). The notion of performatory imperatives is his explanation of operative 
verbal declarations. I think it is somewhat unfortunate that he does not discuss Austin's notion of illocutionary and perlocutionary acts.

The notion of imperatives is important in Olivecrona's account of law and legislation, but he departs from the standard view that they necessarily are commands, prescribing conduct, and addressed to particular individuals. This standard view is also rejected regarding performatory imperatives. Olivecrona writes: "If I hand over a watch to my son saying: 'This shall be your property,' I am using an imperative form of speech. But I am not commanding him to do anything. The imperative is directed towards his acquiring ownership of the watch" (Olivecrona 1971, 134). We constantly use this sort of language in legal transactions. When the appointed person smashes a bottle of champagne against the ship and says "I name this ship the Queen Elizabeth," it has the sense of an imperative "The name of this ship shall be the Queen Elizabeth." (I'm not sure this example, mentioned by Austin, is a legal example, but no matter.) Performatory imperatives have to have an imperative sense, expressed by "shall."

But how do performatory imperatives give rise to rights and duties or legal properties? What are the effects of such utterances? There are two sorts, psychological and legal. Olivecrona considers Austin's examples of naming a ship and of marriage. Suppose that just before the appointed person has a chance to strike the ship with the bottle a man runs forward and strikes the ship shouting "I name this ship the Generalissimo Stalin." The christening ceremony would then be said to have "misfired" and no one would pay heed to it. What is the difference between the successful case and the misfire? The difference, according to Olivecrona, "lies in the effect of the performative sentence on other minds," because of the prevalence of a social custom regarding the naming of ships (Olivecrona 1971, 224; see also Olivecrona 1962, 178). The effect of the utterance is psychological. This is a "real" effect.

The case of marriage is more complicated, as it has many consequences. A few performatory words are used that purport to make the parties man and wife. "What happens?," he asks. "The psychological effect is instantaneous, uniform, and far-reaching" (Olivecrona 1971, 225). The parties are socially classified in a new way, which has consequences of an ethical, religious, and a legal kind. (Compare Olivecrona 1962, 179, where the word "social" is used instead of "legal.") And he goes on to say:

No mystical, supersensible bond is formed by the act of marriage. We need not, for that reason, discuss whether it is a reality or not to be married; it surely is. But the reality is not supersensible. It consists in a certain kind of place in the social context, depending on people's uniform reaction to the marriage ceremony. Take this reaction away and the performatory words are inane. [. . .] If the act is to call forth these effects, observance of the customary or prescribed form is essential. If the performative words of the act are pronounced at the theatre, or in jest, [. . . no real marriage is held to be concluded. [...] [P]ronouncements made outside the proper context are disregarded. (Olivecrona 1971, 225) 
Now it will be noticed that the term "performatory imperative" has neither been used nor mentioned in this account, but we can easily add it in. When at the conclusion of the customary ceremony the minister or official says "I now pronounce you husband and wife," he is saying "Henceforth you shall be husband and wife."

Thus far Olivecrona is describing the complex psychological effects of performative language in the marriage ceremony. What about the legal effects? Are they not something else?

Legal effects, he says, are spoken of in two senses (Olivecrona 1962, 180; Olivecrona 1971, 226). (1) There are legal effects implied in the rules of law with regard to personal relations and property. We talk as if the law had the power to establish a causal relationship between the operative facts and the legal effects. Strictly speaking, the word "effects" is inappropriate. Such effects are not caused by an act of marriage. "These legal effects take place because the law says that they shall take place, as he says in his 1962 article" (Olivecrona 1962, 151), though I have not been able to find this statement in his book. There, he puts the point that what we have is an alteration in the actual situation to which the rules refer; a new fact has been added, so that the applicable rules are now different. (2) Legal effects mean effects that take place through the action of courts or other state agencies. For instance, a man is sent to prison for not supporting his wife and children. Such effects are "actual effects," which are dependent on the psychological effectiveness of the legal rules, because state organs feel bound by the rules. "All real effects of the act of marriage are therefore ultimately psychological effects" (Olivecrona 1971, 226). "On similar lines all sorts of legal acts may be analyzed," he says (Olivecrona 1962, 180).

Olivecrona gives the example of a promise. "The promisor feels himself bound and promisee feels entitled to expect the promisor to act accordingly" (ibid.). These are immediate psychological effects. Secondly, if the promise corresponds to certain requirements of the law, it is relevant to actions by state organs. The promisor's awareness of exposure to a sanction fortifies the immediate psychological effect of the promise.

The consequences of legal performatives, then, are of a double nature: immediate psychological effects, and the relevance of the acts for actions by state organs. The former aspect is easy to understand, and it is a plausible empirical thesis. With respect to the latter aspect, it seems that for Olivecrona psychology also plays a crucial role insofar as "actual effects" are brought about through the medium of a court's feeling bound by the rules. What this feeling is, Olivecrona doesn't say, as far as I can tell. Is it a "mysterious power" that the rules exercise over a judge?

In any case, it is not clear to me that Olivecrona has answered the question of how saying certain words has a legal effect in the first sense, above. The act of undergoing the marriage ceremony changes the rules that are relevant to the couple. New rights and duties are established for them. Is this 
change, too, merely a matter of psychology, as complex a matter as that might be? I don't think we can say this. The new (social) fact of marriage brings it about that different rules are relevant or applicable to them, and that seems to be a non-psychological consequence of the act of marriage. If so the problem remains of explaining how so-called operative facts bring about legal effects in this sense.

It is at this point in his 1971 book that Olivecrona returns to the themes discussed earlier. In particular he takes up the subject of promises and the "creation" of rights. The magical view, that words create rights, must of course be rejected. In its place we find the natural law doctrine, according to which "all rights are supposed to have their origin in promises made by free individuals" (Olivecrona 1971, 242). As he goes on to say, "In legal transactions the words used are not considered as having any force of their own. They are only regarded as means for expressing the will of the parties" (Olivecrona 1971, 243). But the natural law doctrine must also be rejected. (There is an elaborate discussion of Grotius and Pufendorf in Olivecrona 1971, 275-96.) Both the magical view and the natural law view "are based on the assumption that 'legal effects' of a supersensible kind take place" (Olivecrona 1971, 245). But this, as he has already shown, makes no sense. What we need is an entirely different approach.

That approach has been discussed above, the function of legal language. As Olivecrona writes: "Words are certainly tools in legal transactions; and we can study the function of the tools" (Olivecrona 1971, 246). He then expounds his position on the "monetary unit," as well some other legal concepts. Again he reminds us that these words actually denote nothing, not even imaginary entities. And his conclusion is already familiar to us: "The 'hollow' words are like sign-posts with which people have been taught to associate ideas concerning their own behavior and that of others" (Olivecrona 1971, 253; emphasis supplied). The discussion here, however, is less elaborate than in his 1962 article.

In any case, what I think is missing is Olivecrona's own positive account of how all of this is applied to promises. According to the American Restatement (Second) of the Law of Contracts par. 1: A contract is a promise or a set of promises for the breach of which the law gives a remedy, or the performance of which the law in some way recognizes as a duty. Of course, there are many questions about which promises should be enforced and how much a promise is worth. Are promises binding because we rely on them, or do we rely on them because they are binding (see Fried 1981, 18)? There are many theories of legal promises: autonomy theories, preferencesatisfaction theories, coordination and cooperation theories, all of which seem to involve the promotion of trust. Promises are a crucial feature of our commercial economy, as was pointed out years ago by Harry Scherman in an undeservedly neglected book (Scherman 1938). 
Of course, individuals make promises without any awareness of the legal rules governing promises, as Olivecrona acknowledges. And individuals may make promises without intending the legal enforceability or unenforceability of their acts. This is true of the myriad of promises that are made in the everyday, ordinary course of life, such as my promise to meet you for lunch tomorrow. Making a promise is more than uttering certain words "in the right circumstances." Promises are more than resolutions or declarations of intention. Promises involve committing ourselves to a course of action. Promises are a variety of the commitments we make, and these commitments are fundamental to any social life. Austin, as far as I can tell, had nothing to say on this topic, namely, the practice of promising as a moral institution. Nor do the performatory language theorists, who are mainly interested in linguistic rather than normative matters, have much to say on the topic, though their work is useful for it. I think it would have been interesting to have had Olivecrona's views on everyday, nonlegal promises and commitments. Had he started from them he might well have ended up with a different theory of legal language.

As Olivecrona recognizes, one can acquire rights and duties through conduct, without saying the words "I promise." For many years now, I have been bringing my wife three cups of coffee every morning while she is in bed-not all at once of course but over a half-hour period. I have never promised to bring her the coffee, but by now I do have an obligation to bring them to her. Sometimes I ask her whether she wants a fourth cup, but I always tell her that I am making no commitment or promise for the future. Even so, I could probably get around it. As the old perfume advertisement goes, "Promise her anything but give her Arpège."

\author{
Duke University \\ School of Law and Department of Philosophy \\ Durham, NC 27708-0360 \\ USA \\ E-mail: golding@law.duke.edu
}

\title{
References
}

Austin, John Langshaw. 1975. How to Do Things with Words. Cambridge, MA: Harvard University Press. (1st ed. 1962.)

Bingham, Joseph W. 1912. What is the Law? Michigan Law Review 11: 1-109.

Carroll, Lewis. 1876. The Hunting of the Snark. London: Macmillan.

Cohen, Morris R. 1982. Law and the Social Order. New Brunswick, NJ: Transaction Books.

Corbin, A. L. 1919. Legal Analysis and Terminology. Yale Law Journal 29: 163-73.

Fried, Charles. 1981. Contract as Promise. Cambridge, MA: Harvard University Press. 
Golding, Martin P. 1986. Jurisprudence and Legal Philosophy in 20th Century America: Major Themes and Developments. Journal of Legal Education 36: 441-81. Olivecrona, Karl. 1947. Law as Fact. In Interpretations of Modern Legal Philosophies. Ed. P. Sayre, 542-57. New York, NY: Oxford University Press.

Olivecrona, Karl. 1957. The Problem of the Monetary Unit. New York, NY: Macmillan.

Olivecrona, Karl. 1962. Legal Language and Reality. In Essays in Jurisprudence in Honor of Roscoe Pound. Ed. R. A. Newman, 151-91. Indianapolis, IN: Bobbs-Merrill. Olivecrona, Karl. 1971. Law as Fact. London: Stevens \& Sons.

Scherman, Harry. 1938. The Promises Men Live By. New York, NY: Random House. Searle, John R. 1991. How Performatives Work. Tennessee Law Review 58: 371-92. 